\title{
SteFAn ZWEIG No País do FutuRo: UM INTELECTUAL SEM PÁtRia NO OLHAR DA IMPRENSA BRASILEIRA, 1936-1942
}

Carol Colffield ${ }^{1}$

\begin{abstract}
Resumo: A vida e a morte de Stefan Zweig, um dos mais celebrados escritores em língua alemã a exilar-se no Brasil, são vistas como símbolo do drama dos intelectuais perseguidos pelo nazismo. Embora sua presença física como exilado naquele que denominou o "país do futuro" tenha sido breve - somente alguns meses -, no período que se estende entre a primeira chegada como visitante ao Rio de Janeiro em 1936 e o suicídio em Petrópolis em 1942, seu nome esteve presente na imprensa escrita brasileira quase ininterruptamente. A maneira como sua figura foi retratada nos jornais do país ao longo desses seis anos, no entanto, não foi de maneira alguma unânime e evoluiu ao ritmo dos embates político-históricos da época. Assim, este artigo busca expor, por meio de uma seleção de artigos publicados na época, parte dessa evolução através de três momentos: a primeira viagem de Zweig ao país em 1936; a segunda visita em 1940, quando realizou as pesquisas para o livro Brasil, País do Futuro; os meses entre a última chegada em agosto de 1941 e o suicídio em fevereiro de 1942.
\end{abstract}

PALAVRAS-ChAVE: Exilados no Brasil; Literatura em língua alemã; Refugiados do nazismo; Stefan Zweig

\section{STEFAN ZWEIG IN THE LAND OF THE FUTURE: A STATELESS INTELLECTUAL AS SEEN BY THE BRAZILIAN PRESS, 1936-1942}

\begin{abstract}
The life and death of Stefan Zweig, one of the most celebrated German-speaking writers exiled in Brazil, are seen as a symbol of the drama of the intellectuals persecuted by Nazism. Although Zweig's physical presence as an exile in the country he called "the land of the future" was relatively brief, along the period comprised between the first visit in 1936 and his suicide in Petrópolis in 1942, his name was present in the Brazilian written press almost uninterruptedly. The way his figure was portrayed in the country's newspapers during those six years, however, was by no means unanimous and evolved according to the rhythm of the political-historical struggles of the time. This article, by means of a range of selected articles published in the Brazilian press, aims at exposing part of those developments with a special focus on three moments: his first trip to the country in 1936; his second visit in 1940, when he carried out research for Brazil, Land of the Future; the months between the last arrival in August 1941 and his suicide in February 1942.
\end{abstract}

KeYwoRDS: Exiles in Brazil; German language literature; Refugees from Nazism; Stefan Zweig

1 USP, Mestre em Estudos Judaicos, ccolffield@usp.br 


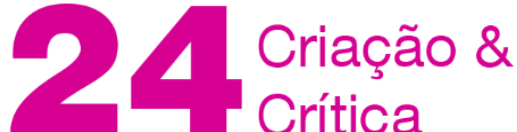

\section{Introdução}

Em 24 de fevereiro de 1942, os leitores dos jornais brasileiros já habituados às más notícias de um mundo em plena guerra foram sacudidos pelo anúncio de um evento ocorrido um dia antes na pequena cidade de Petrópolis: Stefan Zweig, um dos mais celebrados autores europeus em língua alemã, então exilado no Brasil, havia cometido suicídio em sua casa, junto com a esposa, Lotte. Em meio ao grupo de intelectuais forçados a abandonar a Europa entre as décadas de 1930 e 1940, Zweig não era o primeiro nem seria o último a pôr fim à própria vida, mas era certamente um dos mais proeminentes. Seus livros, publicados em diversas línguas, eram lidos em todo o mundo; suas histórias ganhavam os palcos e as telas dos cinemas.

No Brasil, país que visitou pela primeira vez em 1936, já em meio a um exílio que começara dois anos antes na Inglaterra, Stefan Zweig era também muito admirado. Assim, o primeiro encontro com aquele que mais tarde ele mesmo chamaria de "país do futuro" foi amplamente registrado e comentado nos jornais brasileiros. Dada a estatura do autor, o anúncio, ainda durante aquela primeira viagem, do projeto de escrever "um livro sobre o Brasil" criou enormes expectativas. Quatro anos mais tarde, ao retornar ao país para uma estadia mais prolongada durante a qual coletaria material para essa e outras obras em andamento, o interesse do meio jornalístico brasileiro sobre as opiniões do autor austríaco a respeito do país e da situação mundial era ainda maior.

Contudo, se durante a primeira visita a maior parte dos registros exaltava principalmente os talentos e a humanidade daquele intelectual mundialmente conhecido, ao retornar ao Brasil em 1940, em plena ditadura do Estado Novo e com o mundo em guerra, as alusões a Stefan Zweig na imprensa já não eram tão unanimemente favoráveis. Certamente os admiradores eram ainda numerosos, mas haviam também aumentado tanto o volume do coro de detratores da obra e do homem - alguns portadores de visões antissemitas - quanto o número de críticos à postura de distanciamento que Zweig havia assumido como intelectual em relação à Alemanha e seu regime. Após o suicídio, se por um lado a notícia posicionou o drama pessoal do autor e dos outros tantos intelectuais perseguidos pelo nazismo e pelo fascismo em um patamar de destaque perante o público, por outro, não arrefeceu a atitude de críticos que, mesmo dentro do círculo de intelectuais no exílio, entenderam aquela decisão última como um ato de covardia. Parte desse drama se desenrolou nas páginas da imprensa escrita no Brasil. Assim, por meio da exposição de um mosaico das principais manifestações e opiniões sobre Stefan Zweig que circularam nos periódicos brasileiros pretende-se aqui explorar a maneira como sua presença e o trágico desfecho de sua trajetória contribuíram para as discussões em torno a duas questões: a dos exilados do nazi-fascismo residentes no Brasil e a do papel do intelectual em meio ao particular contexto brasileiro e mundial.

Embora o trabalho proponha analisar um período relativamente breve - apenas seis anos - na trajetória de um único personagem sob o prisma da imprensa brasileira, a substancial riqueza de materiais que a pesquisa revelou obrigou a fazer escolhas. Destarte, 


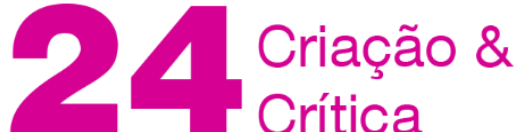

dados os limites do formato, o relato estará focado em três aspectos que, de certa maneira, revelam a evolução do momento histórico em relação aos temas propostos com base na figura do protagonista. Isto posto, em primeiro lugar, revisitaremos, por meio dos jornais da época, as reações à vinda de Stefan Zweig ao Brasil em 1936. A etapa seguinte do trabalho irá explorar alguns aspectos da segunda chegada do escritor austríaco ao país em 1940 e as repercussões veiculadas a respeito do andamento do projeto e posterior lançamento do livro Brasil, País do Futuro. Por último, o foco voltar-se-á às reações suscitadas pelo suicídio de Zweig em Petrópolis e à maneira como o evento foi vinculado à questão dos "intelectuais sem pátria", perseguidos e condenados ao exílio desde as primeiras horas do nazismo.

\section{6, a primeira visita de Stefan Zweig ao Brasil}

Um dos primeiros processos implementados pelo regime nazista na Alemanha a partir de 30 de janeiro de 1933 foi o de alinhar as artes e a cultura à ideologia do regime. Chamado Gleischaltung, o mecanismo tinha como objetivo "limpar" as instituições e organizações culturais de todo elemento "não-alemão" o que atingia tanto as produções artísticas ou literárias consideradas "degeneradas" quanto seus produtores. Foi nesse espírito que na noite de 10 de maio de 1933, multidões de estudantes em dezenas de cidades universitárias alemãs se reuniram para iniciar um macabro ritual de queima de livros. Entre os escolhidos para aquele auto-de-fé estavam inúmeros exemplares da vasta obra até então produzida pelo autor judeu austríaco Stefan Zweig. Os ataques aos intelectuais, porém, não se limitaram a esse infame episódio: incluíram também investidas por parte dos órgãos de propaganda do regime que iam da proibição de publicar ou de expressar-se por qualquer meio a perseguições físicas.

Para escapar do clima de violência, em 1934 Stefan Zweig deixou a Áustria, onde nascera em 1881, rumo à Inglaterra. Porém, pese a não mais poder publicar na Alemanha - proibição essa que se estenderia anos mais tarde a outros países - suas obras, traduzidas em diversas línguas, continuaram sendo best-sellers no mundo inteiro o que fez com que pudesse prosseguir com uma intensa agenda de viagens, palestras e lançamentos. Entre os compromissos estava a participação, em 1936, no XIV Congresso Internacional de Clubes PEN a ser realizado em Buenos Aires, Argentina.

Ao inteirar-se da notícia sobre essa primeira viagem de Zweig à América do Sul, o governo brasileiro estendeu a ele um convite para visitar o Brasil em caráter oficial. Os meios de imprensa anteciparam a chegada do escritor com grande entusiasmo. Várias de suas obras estavam disponíveis em língua portuguesa, e o estilo de suas novelas agradava muito o público brasileiro, assim como as biografias, gênero que Zweig contribuiu a popularizar. A abordagem psicológica de personagens célebres em suas obras, em um momento em que os estudos de Freud atingiam também popularidade, cativava os leitores ao tempo que intrigava e instigava os críticos.

Em 21 de agosto de 1936, dia do tão esperado desembarque de Zweig no Brasil, dentre as muitas manifestações na imprensa merece destaque o artigo publicado pelo 


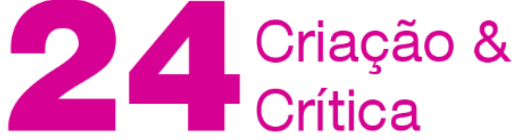

Correio da Manhã. Ali, o articulista - anônimo - já no título caracteriza o autor recémchegado como "un clerc qui n'a pas trahi" [um intelectual que não traiu], referência direta à obra de Julien Benda, publicada em 1927, La trahison des clercs [A traição dos intelectuais]. Esse breve texto se apresenta como um interessante contraponto às manifestações contrárias à atitude assumida por Stefan Zweig em relação à situação na Europa e à sua insistente recusa em vociferar claramente sua oposição ao nazismo. No entanto, para o autor do artigo que inaugura a galeria de olhares que a imprensa brasileira lançou sobre aquele protagonista das letras entre 1936 e 1942, Zweig era um "servidor fiel e infatigável" que jamais "cometera a traição de subordinar os valores espirituais às contingências temporais". E prossegue:

Longe de desinteressar-se, porém, da marcha dos acontecimentos, de encerrar-se na clássica torre de marfim, dos absenteístas timoratos que desfalecem quando tentam olhar face a face a realidade, Zweig é dos que num esforço incessante de compreensão não se contentam em encará-la, mas procuram antes penetrar-Ihe a significação essencial. Num mundo de belicismos múltiplos e exasperados e de deformação extremada do sentimento nacionalista, Zweig, sem descambar para o terreno estéril do utopismo, se mantém sempre fiel ao ideal da paz e da cooperação entre as nações e da compreensão mútua entre os povos. (CORREIO DA MANHÃ, 21/08/1936, p. 3)

Ao longo dos anos, como veremos, cada vez seriam menos numerosas as vozes que se levantavam em apoio a esse universalismo no qual tanto Stefan Zweig quanto Julien Benda acreditavam. Naquele agosto de 1936, porém, o mundo ainda estava por conhecer as profundezas do abismo que em breve seriam visitadas. Enquanto isso, a chegada do austríaco reverberava por todo o meio intelectual brasileiro. Entre as figuras de destaque na primeira fila das manifestações, o escritor Benjamim Costallat que em artigo publicado no Jornal do Brasil referia-se à "honra de ter indicado os livros de Zweig aos seus editores em português", concluindo, "[s]e outros serviços não prestei às letras no meu país, ter iniciado a divulgação de um escritor desse porte é uma satisfação e uma honra que me bastam" (LEÃO, 22/08/1936, p. 5). Na mesma edição, o escritor, jornalista e acadêmico Múcio Leão relatou os minutos que passou na Academia Brasileira de Letras em companhia de Stefan Zweig que no mesmo dia em que aportou no Rio de Janeiro foi recebido pelos também acadêmicos Laudelino Freire, Afrânio Peixoto e Miguel Osório para uma reunião prévia "na intimidade modesta do chá de todos os dias". Dentre as impressões sobre o encontro, Múcio Leão chamou a atenção para a enorme curiosidade de Zweig em relação "a todas as coisas brasileiras - tanto as do espírito quanto as da vida comum". Já quanto ao entusiasmo que a visita despertou no público brasileiro em geral, foi o escritor Viriato Correia um dos que mais intensamente traduziu esse sentimento: 


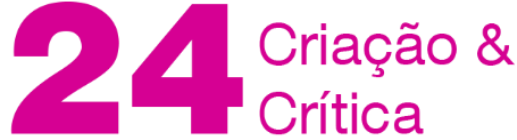

Stefan Zweig não é o escritor deste ou daquele grupo de leitores. É o da totalidade. É o escritor dos brasileiros, de todos os matizes. Não há, no nosso país quem não o tenha lido, desde a costureirinha que devorou de um fôlego os seus romances de amor, até o homem de cultura que leu e releu as suas emocionantes biografias históricas. E no Brasil, Zweig não é querido por esta ou por aquela obra. É por todas. Queremo-lo integralmente. (CORREIA, 23/08/1936, p. 5)

Foi nesse clima que Stefan Zweig deu início a uma intensa agenda no país seguida passo a passo por diversos veículos de informação. Logo após a mencionada reunião para o chá na $A B L$, foi recebido no Itamaraty pelo Ministro de Relações Exteriores José Carlos de Macedo Soares (COSTALLAT, 22/08/1936, p. 7); no dia seguinte, o mesmo ministro ofereceu ao autor um almoço no Jockey Clube do Rio de Janeiro para o qual foram também convidados "representantes da intelectualidade brasileira, diplomatas e pessoas da sociedade" (CORREIO DA MANHÃ, 23/08/1936, p. 2). Na mesma tarde, Zweig foi levado a Petrópolis "em passeio de automóvel, sempre acompanhado pelo secretário de legação nomeado pelo Itamaraty para tal finalidade, Jaime Chermont" (JORNAL DO BRASIL, $22 / 08 / 1936$, p. 7). No dia 24 , às $14: 30$, o escritor reuniu-se com um numeroso grupo de jornalistas brasileiros no hotel onde estava hospedado, o Copacabana Palace. O encontro teve que ser realizado em seu próprio quarto - o 515 - tamanha era a multidão de admiradores que se aglomeravam na recepção (JORNAL DO BRASIL, 25/08/1936, p. 12). Já no dia 25, às 16h, o encontro foi com o Presidente Getúlio Vargas que recebeu Stefan Zweig em audiência especial no Palácio do Catete (CORREIO DA MANHÃ, 25/08/1936, p. 2). Dali, saiu diretamente para uma recepção oficial na Academia Brasileira de Letras, que "atraiu uma verdadeira multidão ao Petit Trianon, sede da ilustre casa de Machado de Assis" (JORNAL DO BRASIL, 26/08/1936, p. 11). Nesse evento, o primeiro a discursar foi Múcio Leão; na sequência, foi a vez de Zweig pronunciar em alemão a fala que preparou especialmente para a ocasião, cuja tradução foi lida pelo cientista e ensaísta Miguel Osório de Almeida. Dizia Zweig:

Uma semana sulcou o navio mares imensos. Uma segunda, quase uma terceira parte da esfera terrestre havia atravessado. Afinal cheguei e então aconteceu o milagre: uma parte do meu ser, partículas vivas da minha essência já se encontravam aqui, antes que o meu físico chegasse a esta nova terra. Meus livros já estavam aqui, em outro idioma, com outras roupagens, nos mostradores das livrarias e, o que é mais, infinitamente mais, - nos corações dos homens. [...] E nós? Que sabemos nós de vós? Que fizemos por vós? [...] Entretanto, que legítimo orgulho, que profundo sentimento de alegria deveis experimentar de serdes escritores e artistas brasileiros! Porque nada conheço de mais admirável do que combater por vossa terra, por um povo, por um idioma, que tem o futuro por si! (JORNAL DO BRASIL, 26/08/1936, p. 11) 
Nesse discurso que inclui as primeiras impressões públicas de Stefan Zweig sobre o Brasil, estão delineadas algumas linhas da obra que ele lançaria anos mais tarde em homenagem ao país. No dia seguinte, na manchete do jornal $A$ Noite, lia-se o compromisso de Zweig: "Serei o camelot do Brasil na Europa". Na entrevista que segue a manchete, porém, observa o repórter que, ao tentar "encaminhar a entrevista em outra direção", ou seja, conhecer as opiniões do protagonista sobre os rumos da literatura na Áustria e na Alemanha, onde "havia uma série de escritores judeus de alto coturno" forçados a deixar o país, Stefan Zweig manifestou: "Prefiro não falar sobre a literatura alemã. Sou um escritor que, em toda a sua vida, evitou a política e hoje em dia é impossível falar em literatura alemã sem tocar em política. Quero continuar afastado dela" (A NOITE, 27/08/1936, p. 3). Essa declaração vai ao encontro da postura do já mencionado Julien Benda para quem, a traição dos intelectuais residia no abandono, por parte dos modernos, das grandes ideias filosóficas em prol de objetivos práticos, ou da imersão no mundo das paixões políticas; em outras palavras, algo que chamou de ética de Cálicles, o sofista que revoltou os importantes pensadores de seu tempo contra a devoção de Sócrates pela filosofia (BENDA, 2014). Essa era a ética que Stefan Zweig se recusou a abraçar apesar da complexidade e das necessidades de seu tempo.

Mas enquanto as palavras dos que se opunham à conduta do escritor austríaco ainda não povoavam as manchetes dos jornais brasileiros, na quinta-feira 27 de agosto de 1936, Stefan Zweig, perante uma enorme audiência reunida no Instituto Nacional de Música no Rio de Janeiro, proferia uma das mais importantes palestras de sua visita - talvez de sua trajetória - cujo conteúdo revelava o cerne de sua consciência. Na fala intitulada "A Unidade Espiritual do Mundo" - publicada na íntegra pelo Jornal do Commercio - o autor estabelecia as premissas de seu universalismo:

Cada um de nós tem uma infinidade de missões a desempenhar em silêncio. Devemos abster-nos de todas as palavras que possam agravar a desconfiança entre os homens e as nações; e em contraposição, temos o dever positivo de aproveitar toda e qualquer ocasião para louvar, conforme o seu mérito, as realizações doutras raças, povos ou nações. [...]. Com o nosso próprio exemplo devemos mostrar, nós, os mais velhos, que a livre admiração pelos valores alheios não diminui a força interior da alma e, ao contrário, a amplia; e só obtém o rejuvenescimento espiritual aqueles que sabem renovar o seu idealismo e o seu entusiasmo. (ZWEIG, 13/09/1936, p. 8)

Após o discurso, que de certa forma sintetizava a conduta de Stefan Zweig, encerrava-se a agenda oficial de eventos programados para ele no Brasil. Porém, o Departamento de Propaganda e Difusão Cultural (o DPDC, precursor do DIP) ainda iria acrescentar um último compromisso: uma fala ao programa "Hora do Brasil" que foi retransmitida no dia 28 de agosto de 1936 por 43 emissoras em todo o país. Apesar da visita ter ocorrido no marco do Serviço de Cooperação Intelectual e promovida pelo Ministério de Relações Exteriores do Brasil, um dos objetivos tácitos do DPDC era extrair 
capital político da celebridade do visitante para fins de propaganda. Para Zweig, 0 intelectual que não desejava ser tribuno, manter-se longe da política se tornava cada vez mais difícil.

\section{$\mathrm{O}$ adeus definitivo ao mundo de ontem}

Durante os anos que se seguiram à primeira viagem de Stefan Zweig à América do Sul, a violência das ações praticadas pela Alemanha nazista aumentava exponencialmente e se espalhava por toda a Europa. Ao mesmo tempo, as perseguições aos judeus se intensificavam e as sucessivas invasões do exército nazista a países europeus haviam deixado a Inglaterra - onde os Zweig estavam refugiados - praticamente como o único bastião de resistência. Dado o risco iminente, em junho do mesmo ano, o casal decidiu partir rumo ao continente americano, começando a viagem pelos Estados Unidos. Após uma estadia de dois meses em Nova lorque, porém, ambos retornaram ao Brasil desembarcando no Rio de Janeiro em 21 de agosto de 1940.

Tal como ocorrera na visita anterior, a chegada foi reportada pela maior parte dos jornais brasileiros; o tom, porém, era diferente. $\mathrm{O}$ mundo em guerra mostrava um rosto muito mais assustador do que em 1936. Internamente, o Brasil, em plena ditadura do Estado Novo, era uma sociedade muito mais complexa e as opiniões em relação a Zweig no meio intelectual estavam divididas. Embora houvesse aqueles que ainda apreciavam sua obra, ecoava com mais força o coro dos que cobravam o fim de sua postura de distanciamento em relação à guerra e ao nazismo. Nesse sentido, é exemplar o texto publicado em 23 de agosto de 1940 no jornal O Radical do Rio de Janeiro cujo título, "Permita-me esquecer a Europa", reproduz as palavras que Stefan Zweig dissera a jornalistas que o entrevistaram assim que retornou ao Brasil. A tese do artigo é introduzida por uma breve análise na qual são elencados os "reflexos profundos na vida mental" oriundos da revolução industrial e onde é mostrado como, antes dela, o romantismo, fundamentado nas leis da imaginação, fazia do escritor um ser "desligado de todas as angústias e sofrimentos da vida de cada dia". Após esse momento, ainda segundo o artigo, viera o realismo que "impunha o debate dos problemas sociais [...] e a reivindicação dos direitos humanos". Nesse sentido, diz o texto, "o fato desse movimento [o realismo] ter colocado em sua verdadeira posição social o escritor" já bastaria para consagrá-lo:

Este [o escritor] não pode ser um displicente ou um requintado, numa sociedade atormentada pelos mais graves problemas humanos. Sua missão é a de esclarecer, de orientar as multidões e não considerar o povo como existente apenas quando o homem da rua se converte em público, quer dizer, em elemento indispensável no mercado literário. Sentir as angústias populares, trabalhar pela sua minoração, dar ao povo a consciência do caminho livre que ele deve percorrer em busca da felicidade social - eis aí o dever mais alto do escritor. E por isso mesmo, nunca como nas horas de 


\section{Criação \&}

tormenta e sobressaltos coletivos é tão árdua e tão digna a missão do intelectual. (O RADICAL, 23/08/1940, p. 2)

Isto posto, a negativa de Stefan Zweig em manifestar-se publicamente a respeito da já gravíssima situação da Europa naquele momento não mais era, segundo o autor do artigo, um direito que o escritor poderia possuir "enquanto permanecer na sua função de escritor" já que a época "não permite a ninguém conformismos que chegam a ser covardias morais diante da tragédia espetacular que a todos atinge" (O RADICAL, 23/08/1940, p. 2).

A ruptura em relação à visão apresentada no texto "O intelectual que não traiu", citado no início deste artigo, é flagrante. Os valores universalistas, tão caros a Stefan Zweig, pareciam não ter mais lugar e já não gozavam do mesmo prestígio do período pós-Primeira Guerra. A defesa de valores pertencentes a toda a humanidade via-se comprometida pelo fato de que, naquele universo que devia ser comum a todos os homens, havia também um Hitler e seus seguidores. Esse aspecto não escapava a Zweig e o impasse filosófico em relação a ele é patente na confissão que o próprio escritor faria poucos meses mais tarde ao jornalista alemão Ernst Feder, também exilado no Brasil: "Nesta guerra nem mesmo é possível combater a guerra" (FEDER, 1941, p. 189).

A frente de ataques, porém, não era única. Setores da imprensa alinhados com a propaganda nazista e integralista, passaram também a perpetrar manifestações injuriosas ao homem Zweig, como esta publicada na edição de 22 de agosto de 1940 no periódico carioca Gazeta de Notícias:

Chegou, ou está para chegar Stefan Zweig [...]. Já esteve entre nós não faz muito, prometendo-nos um livro de propaganda do Brasil [...]. Stefan Zweig, porém, partiu e nunca mais se teve notícia do seu famoso livro de propaganda do Brasil. Apenas um longo artigo apareceu alhures, procedente de sua pena, referindo-se à nossa terra. Nesse artigo, o eminente autor de "Maria Antonieta", tomando-nos por terreno baldio, prognosticava para o Brasil de amanhã o papel de retorta étnica dentro da qual se poderiam realizar as mais curiosas experiências raciais. [...] Não sabemos como o brilhante escritor será recebido desta vez pela nossa grei

2 Fundada em 1875 no Rio de Janeiro, a Gazeta de Notícias destacou-se desde o início pelas inovações técnicas que introduziu na imprensa. Em termos editoriais, manteve-se por décadas como um jornal fundamentalmente governista. Em 1929, apoiou o candidato oficial Júlio Prestes e combateu violentamente a Aliança Liberal de Getúlio Vargas. No início de outubro de 1930, em plena Revolução, o prédio da Gazeta foi invadido e incendiado retornando às atividades somente em 1934. Nesse momento, passou a apoiar o governo Vargas. Segundo afirma Carlos Eduardo Leal em verbete publicado pela Fundação Getúlio Vargas: "De 1935 até o golpe de 10 de novembro de 1937, que instaurou o Estado Novo, a Gazeta de Notícias esteve inclinada a aceitar uma proposta política autoritária, traduzida em termos internacionais nos movimentos nazifascistas. O jornal apoiava abertamente a Transocean, agência de notícias do governo nazista alemão. Segundo depoimento de Osmar Flores, esse apoio provavelmente teria urna contrapartida de ordem material. A Gazeta de Notícias tampouco escondia suas simpatias pelo movimento integralista no Brasil. [...] Durante a Segunda Guerra Mundial, o jornal manifestou extrema simpatia pelos países do Eixo, defendendo a Alemanha e tecendo comentários elogiosos à figura de Mussolini, apresentado como o grande benfeitor do povo italiano" (LEAL, s.d.). 


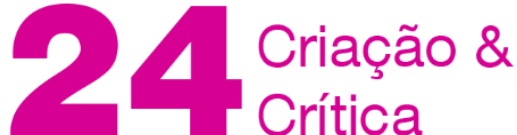

intelectual. Mas certamente o veremos fazendo uma conferência [...]. E nessa conferência, se é certo que as vítimas verão alguns níqueis, não menos certo será, que o sr. Zweig também verá cair dentro dos seus bolsos outros níqueis. E então nos prometerá mais uma vez um livro para o Brasil... (GAZETA DE NOTÍCIAS, 22/08/1940, p. 3)

Contudo, a promessa de publicar um "livro sobre o Brasil" - como até então era chamado -, ao contrário do que o articulista insinuava ser apenas uma manobra do autor austríaco para "encher os bolsos", iria materializar-se menos de um ano mais tarde, em meados de 1941. Na verdade, um dos propósitos da segunda visita de Stefan Zweig ao Brasil, como ele mesmo informara ao jornalista D'Almeida Victor, era coletar material além de dados "para um outro trabalho; a figura de Nóbrega, na sua missão catequizadora" (VICTOR, 03/10/1940, p. 18).

Entre setembro e outubro de 1940, grande parte dos periódicos brasileiros seguiu com atenção os passos de Stefan Zweig por diversos pontos do Rio de Janeiro e também pelos Estados de Minas Gerais e São Paulo. Na capital paulista, em 20 de setembro, a convite de Cásper Líbero, Zweig apresentou mais uma vez no Brasil sua célebre palestra "A Unidade Espiritual do Mundo". De lá voou para Belo Horizonte onde no dia 25 de setembro foi recebido por autoridades e intelectuais em eventos oficiais; fez também "[...] uma série de passeios, alguns dos quais por sua própria iniciativa [...]" (O GLOBO, 27/09/1940, p. 3). Sobre essas viagens, o Correio Paulistano comentou:

Zweig no Brasil não é propriamente um turista, no sentido do viajante que procura paisagens com que se deslumbrar. É sobretudo, o estudioso, à cata de fortes emoções intelectuais, atarefando-se em redescobrir o Brasil, pelo menos naquilo que temos de mais característico e de mais genuíno. Em tudo e por tudo, ele é o antípoda do diletante. Encara os aspectos brasileiros profissionalmente, isto é, sob o ponto de vista do escritor que se propôs firmemente escrever um livro a nosso respeito. [...]. Esperemos o próximo livro de Zweig. (CORREIO PAULISTANO, 28/09/1940, p. 5)

De volta ao Rio de Janeiro, pouco antes de partir para uma viagem previamente agendada a Argentina e Uruguai, Stefan Zweig foi protagonista de um evento na Associação Brasileira de Imprensa. O jornal O Globo publicou uma detalhada reportagem na qual incluiu a fala de Zweig intitulada "A Alma de Viena Dispersa pelo Mundo", que finalizou com uma referência aos tantos vienenses no exílio:

Hoje, Viena deve ser outra coisa, algo que não se sabe ou não se deve querer saber o que seja. Mas o espírito da Viena de ontem ainda não morreu: ele aí está vivo nesses tantos que agora se encontram dispersos pelo mundo, guardando no coração a chama da cultura, dessa cultura que foi e ainda tornará a ser a glória suprema de Viena. (O GLOBO, 24/10/1940, p. 5) 


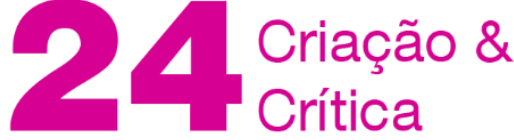

No Aeroporto Santos Dumont, antes de deixar a capital, Zweig conversou com jornalistas e adiantou que na volta planejava visitar demoradamente a Bahia e sobretudo a Amazônia. "Esta segunda parte das viagens que farei pelo Brasil é indispensável... Para escrever convenientemente o livro, aliás já começado, não poderei deixar de percorrer a grande maravilha amazônica" (O GLOBO, 26/10/1940, p. 3). O voo que levava os Zweig a Buenos Aires fez ainda uma escala em Porto Alegre onde o casal foi recebido por admiradores e jornalistas. Em entrevista publicada pelo Diário de Notícias da capital gaúcha, Stefan Zweig informou que o "livro sobre o Brasil" sairia também na Argentina. Quanto a esse aspecto, o escritor teria informado: "[...]minha atual viagem, além da finalidade de atender ao convite de associações culturais daquela República, tem a de ultimar as providências para a sua publicação" (DIÁRIO DE NOTÍCIAS, 27/10/1940, p. 18). Outro dos objetivos da viagem - este não declarado na reportagem - era o de tramitar vistos de residência permanente no Brasil, os quais foram concedidos pelo Consulado Geral em Buenos Aires em 5 de novembro de $1940 .^{3}$

\section{A questão dos "intelectuais sem pátria"}

Quando passadas três semanas, no dia 15 de novembro de 1940, os Zweig regressaram ao Brasil, juridicamente, fizeram-no como residentes permanentes. Aquele era um momento em que apesar das fortes restrições do governo brasileiro à entrada de estrangeiros intensificava-se o afluxo de exilados, entre eles muitos intelectuais que, de uma forma ou outra, conseguiam chegar ao Brasil em busca de refúgio ou ainda de passagem para outros destinos. Isso fez com que a questão passasse a merecer maior destaque na imprensa.

Nesse contexto, cabe destacar a iniciativa do jornal $O$ Globo que, em 6 de janeiro de 1941, anunciou uma série de reportagens baseada em depoimentos de algumas figuras radicadas naquele momento no Brasil; o título: "Como vivem, no Rio, os exilados da guerra?". A primeira reportagem da série trazia como protagonista Stefan Zweig, o exilado mais conhecido no país. ${ }^{4}$ Não obstante o tom por vezes ufanista da apresentação das reportagens, o conjunto constitui um importante patrimônio de história oral cuja proposta era apresentar a vida dessas figuras a partir de suas próprias vozes. Os relatos em primeira pessoa daqueles "soldados da inteligência, das artes e das almas" - como o jornal os denominou - proporcionavam ao leitor uma visão mais próxima das suas trajetórias antes

\footnotetext{
3 Fichas Consulares de Qualificação de Stefan e Charlotte Zweig. Fonte: Arqshoah/LEER.

4 As demais reportagens da série publicada em $O$ Globo tiveram como protagonistas: o jornalista polonês Witold Ipohorski Lenkiewicz, economista e redator político do órgão oficial de Varsóvia, Correio da Polônia (O GLOBO, 08/01/1941, p. 3); o joalheiro russo naturalizado francês Leonard Rosenthal, "cujas compras de pérolas constituem sete oitavos da produção mundial” (O GLOBO, 10/01/1941, p. 1; O GLOBO, 11/01/1941, p. 3); o compositor polonês Michal Kondracki (O GLOBO, 14/01/1941, p. 5); o jornalista e combatente polonês Casimiro [Kazimierz] Konecki (O GLOBO, 16/01/1941, p. 4); o médico polonês Waclaw Korabiewicz (O GLOBO, 17/01/1941, p. 3).
} 


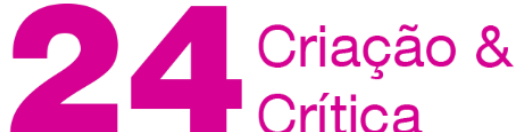

da chegada ao Brasil, e também da maneira como haviam reconstruído suas vidas no país, o que faziam, o que pensavam:

Pondo um mundo entre si e o teatro do drama inaudito, o exilado faz o balanço. Uns, tinham perdido apenas o lar. Apenas o lar. Outros, os entes queridos. Não se pensou, nos primeiros momentos, nas enormes fortunas afogadas pela catástrofe, queimadas no pavoroso incêndio, esmagadas pelos "tanks" da "civilização". (O GLOBO, 10/01/1941, p. 3)

A iniciativa d'O Globo não passou despercebida por aqueles contrários à presença dos exilados. Mais uma vez, a Gazeta de Notícias voltaria à carga já no dia seguinte à publicação da primeira reportagem da série citada. Embora utilizasse o mesmo título do concorrente, o tom da reportagem descortinava um propósito oposto voltado a descaracterizar as enormes dificuldades vivenciadas pela maior parte dos exilados. No corpo da reportagem, entre comentários sarcásticos, o autor propõe iniciar pelo que chamou "as origens":

O começo é assim: - a vassourada militar do Reich alemão passeia sobre a Europa. Uma legião infinita de sujeitos e sujeitas pega o primeiro navio e vem para um lugar que lhes disseram ser muito bom e aprazível: é a capital de Buenos Aires, chamado Rio de Janeiro. Eles não sabem bem onde fica, mas não faz mal. Lá já os aguardam alguns milhares de compatrícios e eles lá terão tudo. [...] Chegam, dão entrevistas aos piolins da imprensa bocó, dizem cobras e lagartos dos Srs. Hitler e Mussolini, afirmam sua fé na democracia e no Dr. Churchill e estendem os olhos para a cidade ingênua que os espera. [...]. (GAZETA DE NOTÍCIAS, 11/01/1941, p. 8)

O nome de Stefan Zweig não poderia deixar de estar presente nas palavras que, segundo informa o repórter, trocou com duas entrevistadas, uma belga e a outra francesa:

[...] "Mr. Zweig vive trés bien no Brasil. Já vendeu os direitos autorais de um livro por 50 contos, conforme lhe [sic] contou uma amiga".

A outra pergunta, no seu francês de flamenga:

- Não há escritores no Brasil? Eles recebem quanto?

- Dez por cento sobre a venda dos livros", -informamos.

- Et alors, Mr. Zweig fez um ótimo negócio!"

- Não há dúvida, pensamos nós que sabemos de brasileiros como Rocha Pombo, que quase morreu de fome... E ainda pagamos o "cocktail" das exiladas... [...] (GAZETA DE NOTÍCIAS, 11/01/1941, p. 8) 


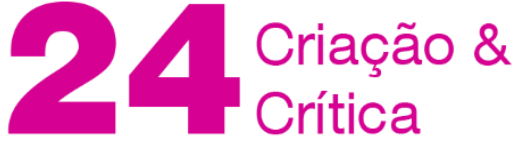

\section{O "livro sobre o Brasil": expectativas e polêmicas}

Stefan Zweig, no entanto, alheio ou não a esses comentários adversos, prosseguia com seus inúmeros planos e em janeiro de 1941, após visitar a Bahia, Recife e Belém do Pará, encerrava a segunda estadia no Brasil. Partiu então para os Estados Unidos onde encontraria editores norte-americanos a fim de discutir o lançamento do "livro sobre o Brasil" em português, inglês e alemão (O GLOBO, 07/01/1941, p. 4). Durante os longos meses em que permaneceu em Nova lorque, porém, a presença de Zweig nos jornais e revistas brasileiros se manteve constante. Não somente se noticiava a respeito de suas atividades como também eram publicados textos de sua autoria. Um deles, que apareceu em 6 de março de 1941 na Revista Diretrizes e intitulava-se "O Martírio do Silêncio", desvenda as impressões de um autor que, apesar de pedir a seus interlocutores que o deixassem esquecer a Europa, carregava permanentemente consigo a condena de seu continente e dos milhões que lá haviam ficado e que, paulatinamente, transformavam-se em uma insuportável ausência:

Todos nós sabemos como começou a grande tragédia. Queimaram-se livros e expulsaram-se cientistas e escritores. O mundo inteiro sentiu-se consternado. No entanto ninguém sabia que a supressão da liberdade intelectual pelos nazistas era apenas um prelúdio do que ia acontecer. [...] É como se todo o país, com todas as suas vilas e cidades, com todos os seus milhões de habitantes, houvesse sido tragado pelo chão. As cartas deixam de chegar, já não existem notícias merecedoras de crédito. As vozes dos parentes e amigos, dos poetas e escritores, emudeceram de repente. Não surge do silêncio um só sinal... às vezes, um deles consegue escapar, cruza a fronteira e penetra nos países neutros. [...] Conte-nos - pedimos conte-nos o que se passa lá". Porém, ele ainda não aprendeu a falar novamente. (ZWEIG, 06/03/1941, p. 6)

Com Zweig ainda nos Estados Unidos, em junho de 1941, começou finalmente a ser anunciado o lançamento tão esperado. O título escolhido para o livro: Brasil, País do Futuro. A obra, que chegou às livrarias brasileiras publicada pela Editora Guanabara, com tradução de Odilon Gallotti e revisão histórica de Afrânio Peixoto - que também escreveu o prefácio -, teve um capítulo cedido com exclusividade ao grupo de comunicação Diários Associados, de Assis Chateaubriand, que o publicou em primeira mão na edição de $1^{\circ}$ de julho de 1941 d'O Jornal.

O público brasileiro respondeu ao livro de maneira favorável esgotando rapidamente as primeiras edições. A recepção no meio jornalístico e intelectual, porém, com raras exceções, oscilou entre o moderadamente crítico - que apontava principalmente questões formais, inexatidões históricas ou estatísticas - e o abertamente hostil. Entre as últimas, havia manifestações cujo perfil extrapolava a crítica puramente literária, mirando o homem e principalmente suas origens. Exemplo é o artigo escrito pelo engenheiro 
integralista Paulo Fleming publicado em 17 de agosto de 1941 também pela Gazeta de Notícias. Ali, o ataque ad hominem se faz presente logo nas primeiras linhas do artigo. Dizia Fleming:

"Quem é Stefan Zweig? Respondo: um tipo padrão de escritor burguês. Creio que nessa constatação encerrei, de maneira cabal, os elementos necessários para uma boa crítica do livro "Brasil - [sic] País do futuro". (FLEMING, 17/08/1941, p. 2)

O autor da crítica não esconde nessa passagem o propósito de amalgamar em sua análise o homem e a obra. No entanto, provavelmente ciente de que sua abertura não explicitava de forma clara como seria feito o vínculo, prossegue:

De início, quero observar que o escopo principal do escritor burguês consiste em fazer da literatura a melhor das fontes de renda. São consequentemente artistas sem mensagem. (FLEMING, 17/08/1941, p. 2)

E mesmo quando algumas linhas à frente o texto parece abrir espaço para um certo reconhecimento em relação ao escritor austríaco, o jornalista o faz no sentido de afirmar que poucos conseguem "atingir tão profundamente a superfície das coisas". Nesse ponto se encontra a principal queixa do crítico que acusa Zweig de não somente ter tratado o Brasil de maneira superficial, mas também maliciosa. Ao tentar descrever essa impressão, destila claros preconceitos e invoca velhos mitos:

Acontece, porém, que por um desses descuidos que muitas vezes são vítimas as agudíssimas (tão agudas que espetam) inteligências semitas, derramou, possivelmente sem querer, certa dose de veneno aqui, ali e acolá. Nada, contudo, de muito escandaloso -o homem é mestre em dar no cravo e na ferradura. Acende uma pequena lanterna ao Demo mas não incorre absolutamente no pecado de deixar o Senhor às escuras. (FLEMING, 17/08/1941, p. 2)

Já o artigo também publicado na segunda quinzena de agosto de 1941 na revista Novas Diretrizes fundada e dirigida por Azevedo Amaral $^{5}$ escancarava as portas

5 Nascido no Rio de Janeiro em 1881, Azevedo Amaral foi um dos mais conhecidos expoentes do pensamento
autoritário brasileiro. No primeiro número da revista que fundou em novembro de 1938 - e que dirigiu até o
ano de sua morte, 1942 - Amaral destacou em editorial a "orientação exclusivamente nacionalista de tudo
que se publicar em suas páginas" afirmando equivaler estas "a um programa de solidariedade incondicional
com a ordem política de que o Estado Novo é a expressão orgânica e cuja direção única cabe e não pode
deixar de caber ao Chefe da Nação" (NOVAS DIRETRIZES, nov. 1938, n. 1, p. 2). Entre os diversos assuntos
referentes à realidade nacional tratados primeiro mensalmente e mais tarde quinzenalmente, a questão dos
refugiados judeus perseguidos pelo nazismo e pelo fascismo era recorrente. O tom dos artigos sobre esse
tema, no entanto, revelava menos a preocupação com essas populações do que com a manutenção da
preponderância étnica da "raça básica brasileira". Embora fosse textualmente negado qualquer preconceito
antissemita, a tônica preponderante em relação aos judeus que aqui tentavam chegar aproximava-se 


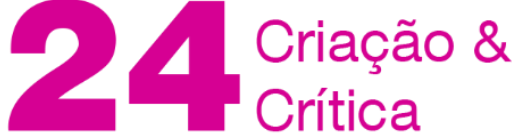

previamente abertas por Paulo Fleming. Após discorrer sobre a ausência de obras de qualidade que retratassem o Brasil e suas características, o autor do texto anônimo ironiza as próprias expectativas em torno a um livro, "[p]ublicado em várias línguas e precedido pelo clamor da publicidade organizada e dirigida pelas agências judaicas". No mesmo tom, afirma ainda:

Enfim, um grande homem assegurava que a nossa Pátria tem um grande futuro. Há muito tempo que os brasileiros modestos e obscuros, como um José Bonifácio e um Pedro II manifestaram a mesma opinião. Mas os judeus conservam ainda o monopólio da profecia e o prognóstico do Sr. Zweig foi recebido como a expressão oracular de uma verdade proclamada pela Sinagoga... [...] 'O Brasil, país do futuro' [sic] dava a medida do que pode valer para nós a amizade de um israelita bem instalado na vida. (NOVAS DIRETRIZES, ago. 1941, pp. 24-27)

Embora admita ainda não ter lido o livro - algo no mínimo questionável para quem faz uma resenha -, o crítico desfere um virulento ataque à obra ao longo de quatro páginas; suas referências, revela, foram duas colunas escritas pelo jornalista Pedro da Costa Rego publicadas entre 6 e 7 de agosto de 1941 no Correio da Manhã. As críticas de Costa Rego ao livro de Zweig, no entanto, embora duras - e dirigidas à obra, não ao autor -, concentravam-se fundamentalmente em aspectos apontados por ele como "inexatidões e exageros" que, por tratar-se de "livro de autor famoso, cujo tema é nossa vida, nossa origem, nossa maneira de compreender o mundo [...]", constituíam "[...] fato público, no sentido quase de fato político, podendo gerar conceitos de repercussão errônea" (REGO, 06/08/1941, p. 2). Costa Rego, contudo, a título de preâmbulo às críticas que apontava em sua resenha, esclarecia: "Estou muito longe de negar a Stefan Zweig o valor e a seu livro de agora a boa intenção" (REGO, 06/08/1941, p. 2).

Mas não era essa a postura que transparecia na Novas Diretrizes. Um mês depois da primeira crítica, a revista voltou-se novamente contra Brasil, País do Futuro. Em um primeiro momento, o autor do artigo - também mantido no anonimato -, após admitir ter usado um tom "áspero" no texto do número anterior, tenta antecipar uma certa mudança de opinião em relação ao que nele foi dito quanto à figura de Stefan Zweig: "A leitura do seu livro nos convenceu de que ele não é mal-intencionado" (NOVAS DIRETRIZES, set. 1941, pp. 8-13). Porém, poucas linhas adiante, retoma a crítica baseada em preceitos raciais. $\mathrm{Na}$ verdade, considerava que em Brasil, País do Futuro, Zweig estaria revelando "um dos traços mais característicos da mentalidade dos homens de sua raça" que, afirma, aprende "por meio de tudo que se diz em letra de forma" graças à sua milenária tradição talmúdica. Porém, prossegue, "tirem-no das livrarias e ponham-no em face da realidade física ou

invariavelmente de passagens como esta: "Estamos pleiteando perante o governo da República medidas de defesa da etnia nacional e de proteção de nossa tranquilidade doméstica contra a formação de quistos alienígenas incomparavelmente mais sérios que aqueles que ora começamos a combater nas regiões meridionais do país" (NOVAS DIRETRIZES, jun. 1939, n. 8, p. 11). 


\section{$244_{\text {cinacabo o }}^{\text {cal }}$}

social" e sua incapacidade se revela, tornando o judeu, segundo ele, "o mais impróprio dos analistas da realidade" pois:

Vive no meio de uma sociedade qualquer ou atravessa os mais empolgantes cenários da natureza, sem escapar do ghetto espiritual, a que o condena a inexorável fatalidade do psiquismo da sua raça. [...]. Tangido pelo nomadismo que lhe ferve no sangue e aguçado provavelmente pelo desejo de uma expedição lucrativa aos trópicos, [...] [Stefan Zweig] veio ao Brasil. Aqui, no meio de um ambiente radicalmente diferente sob todos os pontos de vista daquele a que se achava mais acostumado, o peregrino hebreu não teve uma impressão forte e original de coisa alguma. (NOVAS DIRETRIZES, set. 1941, p. 9)

Mas nem tudo eram espinhos. Em meio às críticas houve personagens que, talvez menos pelo livro em si, e sim na tentativa de amenizar a onda de ataques à obra e ao autor, ressaltaram aspectos positivos da mesma. Entre eles estava o escritor e jornalista capixaba Newton Braga que, apesar de declarar não ser fã de Stefan Zweig por considerá-lo excessivamente literato e dono de um estilo muito adornado, reconheceu em Brasil, País do Futuro a impossibilidade de "ficar indiferente ao encantamento de sua explanação e à notável boa vontade com que se houve para, em tão curto prazo, realizar os enormes estudos necessários para escrevê-la". Além disso, acrescentou Braga, considerando o caráter de "exaltado canto de louvor ao Brasil e, pela imensa divulgação que deverá ter mundo afora será, a meu ver, o melhor trabalho de propaganda que terá tido a nossa terra, sob qualquer ponto de vista" (BRAGA, 31/08/1941, p. 18).

Dias mais tarde, o mesmo enfoque era trazido pelo político e jornalista Otto Prazeres que, no Jornal do Brasil, referia-se à agressividade de muitas das críticas dirigidas a Brasil, país do futuro, destacando a impropriedade de exigir de tal obra qualquer precisão nas estatísticas ou na análise, justamente por tratar-se de um trabalho que era "um hino à nossa terra, um livro de quem por ela se apaixonara, um livro, enfim, de sentimento, de exaltação". Para fundamentar sua tese, Prazeres recorre à seguinte comparação:

Um indivíduo que se coloca em cima de uma árvore alta e dá a sua impressão da paisagem não pode, é lógico, ser desmentido no que vê ou no que sentiu, pelo que ficou cá em baixo, no chão, e que, ficando, vê a mesma paisagem de forma diversa e não alcança os detalhes que figuram ao longe, para o que ficou no chão quase invisíveis ou mesmo invisíveis. (PRAZERES, 10/09/1941, p. 5)

Já o escritor e jornalista Tristão de Athayde - pseudônimo de Alceu Amoroso Lima -, embora também admitindo resistir à literatura de Zweig por não atender esta ao "grande espírito do século XX [...] mas sim à superficialidade brilhante e afetada", não se uniu às 


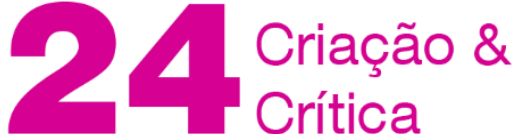

correntes que trataram Brasil, país do futuro de forma hostil. Assim como os dois comentaristas anteriormente citados, destacou na obra,

[...] uma visão impressionista, e otimista de nossa terra, feita por quem apenas tocou de leve a sua complexa realidade, mas que denota uma grande simpatia e uma compreensão justa de vários traços de nossa psicologia coletiva [...] cheia de verdadeiro espírito de compreensão de nossa alma e por vezes de nossa história, a despeito de pontos de vista contestáveis. (ATHAYDE, 19/10/1941, p. 8)

Houve ainda um grupo de críticos abertamente favoráveis ao livro. Entre as figuras que o compunham destaca-se o jornalista Mário Cordeiro que no Diário Carioca expressou que Brasil, País do Futuro não era "caricatura, nem retrato retocado, desses que transformam matronas em misses". Segundo o autor, a força do livro de Zweig residia em que "não ficou no lugar comum dos que nos visitam", mesmo porque,

[...] não foi escrito por informações, não foi notado de longe, nos bairros elegantes, nos hotéis de luxo. Ao contrário. Stefan Zweig andou perambulando, demoradamente, de bonde, de ônibus e a pé: subiu e desceu os morros cariocas; ouviu os nossos sambas; visitou as nossas favelas; perdeu-se na agitação cosmopolita dos centros urbanos das principais metrópoles do país; viajou São Paulo, Bahia, Recife e o Amazonas; foi vendo e anotando essas coisas curiosas e felizes que enriquecem as páginas magníficas do seu livro. (CORDEIRO, 14/09/1941, p. 19)

Foi justamente essa a atmosfera mista que aguardava Stefan Zweig na ocasião de sua última e definitiva chegada ao Brasil. Ao desembarcar no Rio de Janeiro em 28 de agosto de 1941, surpreso principalmente com as manifestações contrárias ao livro, apelou aos brasileiros, por meio dos repórteres que o aguardavam no porto, que não vissem "o menor intuito de molestar a grandeza e a maravilha de caráter do povo brasileiro" (DIÁRIO CARIOCA, 28/08/1941, p. 1). Entretanto, Zweig saberia, o país que havia escolhido como última etapa de seu exílio não era o mesmo que encontrara em 1936. O nacionalismo insuflado pelas políticas de propaganda do governo Vargas havia reduzido a presença de eventuais brechas pelas quais pudessem passar manifestações outras que não fossem de elogio ou bajulação em relação ao país. Essa mudança foi sentida e transmitida ao seu amigo Ernst Feder, como mostram os registros no diário deste:

[Zweig] achou o Brasil completamente transformado, chove dinheiro, agora têm todos os luxos, a sensação de inferioridade em relação a todos os estrangeiros, incluindo a Argentina substituído por acentuado nacionalismo, que atribui todas as novas conquistas a Getúlio Vargas. (FEDER, 1941, pp. 76-77) 
Assim, quiçá para afastar-se das polêmicas que o encalçavam, Stefan Zweig optou no Brasil por instalar-se em meio à calma de Petrópolis onde alugou uma casa no número 133 da Rua Gonçalves Dias, modesta, mas de cuja varanda tinha uma vista excepcional da região serrana fluminense. Sua rotina era simples, porém intensa, alternando trabalho, as visitas de um pequeno círculo de amigos e o xadrez, justamente o protagonista da última história que escreveu, publicada postumamente; uma espécie de manifesto contra as agruras do exílio e única obra com referências diretas ao regime nazista.

\section{"No derradeiro olhar, a paisagem suprema"6}

O suicídio de Stefan e Lotte Zweig ocorrido em 23 de fevereiro de 1942 levou à casa do autor em Petrópolis uma multidão de jornalistas, amigos e curiosos que se acotovelavam nos diversos ambientes. Os jornais do dia seguinte revelavam, em palavras e imagens, inúmeros detalhes do ato, as últimas determinações e declarações que Zweig deixou por escrito, além de depoimentos dos empregados da casa, da proprietária do imóvel e de diversas outras figuras que compartilhavam o dia-a-dia do casal. Esses relatos eram em geral acompanhados pelas mais variadas especulações sobre o porquê do suicídio.

Nessa atmosfera, a busca por entender as razões que levaram Zweig a tirar a própria vida naquele contexto histórico particular fez com que a questão dos exilados ganhasse um novo protagonismo nas discussões. Nos dias seguintes, desfilaram nas páginas dos jornais entrevistas, artigos e comentários produzidos pelos mais diversos personagens: políticos, amigos, intelectuais brasileiros e exilados. Parte deles opinava que a situação na Europa e a condição de "intelectual sem pátria" haviam tido um peso fundamental na decisão de Stefan Zweig. Ao mesmo tempo, as informações que se avolumavam a respeito das providências e detalhadas instruções levavam a concluir que seu ato não fora praticado por impulso, e sim fruto de uma longa reflexão.

De qualquer maneira, fica evidente nas análises que para boa parte dos comentaristas a tragédia de Zweig tinha um caráter universal, o que contribuiu ao protagonismo dos testemunhos de outros intelectuais europeus que, tal como Zweig, estavam também exilados no Brasil. Nesse sentido, o panorama dos jornais do dia em que foi revelada a notícia mostra um claro consenso no sentido de inter-relacionar o suicídio de Zweig à guerra e às perseguições aos judeus da Europa. Várias manchetes daquele 24 de fevereiro de 1942 classificavam o gesto de Zweig como herança, legado, discurso, arma. A edição matutina d'O Globo, por exemplo, estampava na primeira página: "O Último libelo de Stefan Zweig contra a escravidão da Europa”, afirmando já no epílogo:

[...] matou-o aquilo que para ele é o processo da morte da Europa, a agonia da cultura. [...] E, paradoxalmente, a vida Ihe concedeu na morte a maneira

6 Manchete publicada pelo jornal $A$ Noite adaptada da carta-despedida que Stefan Zweig deixou ao Prefeito de Petrópolis reproduzida na página 3 da edição de 24 de fevereiro de 1942 do mesmo periódico. 


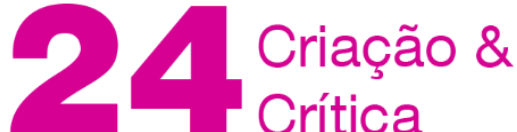

de protestar em nome da grandeza do espírito e do amor à liberdade contra tudo que leva a Europa em funeral. (O GLOBO, 24/02/1942 m., p. 3)

Já na manchete da edição vespertina do mesmo jornal, lê-se: "Toda a angústia e revolta do mundo encarnadas na morte trágica de Zweig". No corpo do artigo, claras referências às perseguições aos judeus da Europa:

Esse suicídio não representa uma renúncia, porque vale por um protesto contra as perseguições infligidas ao espírito humano, contra as afrontas impostas a uma raça a que devem os templos da civilização tanto óleo fino suas lâmpadas. (O GLOBO, 24/02/1942 v., p. 2)

Mas 0 artigo vai além, interpelando os responsáveis pelos pesados ataques dos meses anteriores a Brasil, país do futuro, que fizeram com que se gerasse na imprensa um clima hostil em relação ao escritor austríaco:

Desta vez ninguém indagará quanto se pagou a Stefan Zweig pelo seu supremo protesto, nem dirão os partidários de Hitler, nem dirá o quintacolunismo, nem os maus brasileiros dirão, empenhados em implantar no Brasil, cadinho de todas as raças, os ódios que a política impiedosa e sinistra do Führer tem espalhado pela terra, que o glorioso suicida judeu falou mal da nossa terra ou não soube observar e sentir. (O GLOBO, 24/02/1942 v., p. 2)

Em linha similar, o Diário de Notícias descrevia o suicídio de Zweig como o "desfecho brutal de um dos muitos dramas pessoais decorrentes da guerra desfechada pelo nazismo e da sua torva política de perseguição racial e de opressão dos povos" (DIÁRIO DE NOTÍCIAS, 24/02/1942, p. 3). Mas talvez tenha sido o Jornal do Commercio o periódico que posicionou de forma mais contundente o suicídio de Zweig no centro da questão dos intelectuais exilados:

Esse doloroso acontecimento desperta a atenção de todos para uma singular tragédia espiritual até agora adivinhada e pressentida mas não confessada: a tragédia dos grandes escritores que a intolerância dos fanatismos ideológicos fez deixarem a pátria para conservar a liberdade, o direito de pensar e muitas vezes a própria vida. (JORNAL DO COMMERCIO, 24/02/1942, p. 3)

Ao longo dos dias que sucederam ao suicídio, os detalhes sobre a morte passaram também a dar lugar a análises com um alcance em que transparecia o lado humano de Zweig. A edição d'O Globo de 27 de fevereiro de 1942 trouxe o artigo "Stefan Zweig e os intelectuais sem pátria", no qual é explorada a maneira como o autor austríaco foi ao auxílio de outros exilados que, sem gozar de sua celebridade ou meios, procuravam-no. $\mathrm{Na}$ reportagem, o leitor acompanha o depoimento do sociólogo alemão Bruno Kreitner que, 


\section{Criação \&}

tendo estado à beira da deportação em 1941, contou ao jornal as diversas vezes que Zweig se solidarizou com sua situação e se fez presente para ajudá-lo, "levando-o mesmo para sua residência em Petrópolis por alguns dias, e com ele trabalhando na complexa tarefa de seus manuscritos cheios de emendas e entrelinhas". A matéria d'O Globo reproduz inclusive uma carta que Stefan Zweig enviou a Kreitner em 27 de janeiro de 1942 - apenas três semanas antes do suicídio - na qual revela um de seus planos:

[Um] Anuário de Emigração de 1941, 1942 e, assim por diante, que encerre uma escolha dos melhores trabalhos dos emigrados, e desse modo mostre como continuam escrevendo. Este Anuário não seria somente um magnífico livro literário senão ainda um parcial documento histórico de primeira ordem. Haveria um anuário alemão com Thomas Mann, Heinrich Mann, Feuchtwanger, Georg Kaiser, Unruh, Cassierer, extratando o melhor que escreveram no ano de 41 e 42, no exílio. Haveria do mesmo modo um anuário austríaco com Werfel, Beer Hoffman, Bertold Viertel, Auernheimer, Coudenhove, haveria ainda um anuário francês com Maurois, Bernanos, Romains, Pierre Cot, etc. [...] Poderia haver também um anuário espanhol do exílio, com Ortega y Gasset e todos os outros. A composição alemã e austríaca poderia ser feita por um amigo meu em Nova York, ou por Klauss Mann e você poderia aqui dirigir os assuntos técnicos. (O GLOBO, 27/02/1942, p. 4)

A Revista da Semana, por sua vez, ouviu o escritor alemão exilado no Rio de Janeiro Leopold Stern que, assim como Bruno Kreitner, procurou mostrar um Stefan Zweig com sua mente no futuro:

A última vez que estivemos juntos, não me recordo bem o dia, Zweig estava ocupado em reunir material para o ensaio que estava escrevendo sobre Montaigne. Ele pretendia prolongar o contrato de sua casa por mais um ano, tal o desejo de continuar vivendo no país que ele amava sinceramente. (GONÇALVES, 28/02/1942, p. 16)

Essas manifestações, no entanto reforçavam ainda mais a pergunta tantas vezes feita: "por que?". Por mais descabida que pareça a possibilidade de obter uma resposta que escape ao puro universo da especulação, foram muitas as páginas de jornais dedicadas a enfrentá-la. Embora surgissem conjecturas que buscavam associar o suicídio a motivações financeiras $^{7}$ ou ainda ao perfil psiquiátrico do protagonista $^{8}$, a maioria das análises

7 Um dos propagadores dessa "teoria", desmentida por diversas fontes, foi o escritor e acadêmico Cláudio de Souza que afirmou a um repórter: "Stefan perdera tudo ou quase tudo quanto possuía na Europa. De homem rico que era, acabou no escritor que vivia somente dos direitos autorais de seus livros" (O GLOBO, 24/02/1942, p. 2).

8 Quanto a esse aspecto, o médico Cláudio de Araújo Lima lançou no início de 1943 o livro Ascensão e Queda de Stefan Zweig, ensaio em que analisa o temperamento de Zweig e atribui a certas características de sua personalidade, as causas que o levaram ao suicídio. Opiniões sobre o livro ganharam também espaço na 
considerava a guerra, a situação da Europa e a condição de exilado do autor como as fontes que o impulsionaram à decisão de dar fim à própria vida. Para fundamentar essa ideia os jornais também recorreram a testemunhos de figuras do exílio próximas a Stefan Zweig. Uma delas, o também austríaco Paul Frischauer, exilado no Brasil entre 1940 e 1945, e que há meses trabalhava com Zweig em um roteiro cinematográfico sobre a Marquesa de Santos. Eis um fragmento do artigo escrito por Frischauer publicado no jornal $A$ Noite do Rio de Janeiro:

Há dez anos, [...], liguei-me a Stefan Zweig não somente pela amizade espiritual em tempos anteriores, mas também pelo mesmo incerto destino, o destino dos "sem pátria", dos emigrados, que em terras outras têm forçosamente de estabelecer o mais íntimo contato pessoal. Deixamos a pátria, nós ambos, desde que o chamado "Terceiro Reich", ao mesmo tempo que bania os princípios de humanidade, expulsava também os humanistas do seu campo de influência. [...] Quando a guerra irrompeu na Europa, [...] [Zweig] procurou um novo ambiente tranquilo e feliz e encontrou o Brasil. [...] $\mathrm{E}$ aqui estávamos nós, outra vez convivendo intimamente, ligados pelo mesmo destino. [...]. O diálogo que tive, à minha chegada, com Stefan Zweig, foi bem característico:

- Eis o país em que eu desejaria morrer, disse-me ele.

[...] O pessimismo havia se apoderado completamente de seu espírito. Não pensava mais na vida. Só pensava na morte. Qualquer que fosse o assunto abordado, a despeito de todos os meus esforços, ele fazia convergir, obstinadamente, ao mesmo tema. [...] Zweig compartilhava a minha opinião de que a vitória seria "nossa".

- Eu, porém, não chegarei a assisti-la - disse-me à despedida. (FRISCHAUER, 25/02/1942, p. 2)

Outra dessas figuras foi o francês Max Fischer, diretor literário da Editora Flammarion de Paris, que descreveu o preço que os anos como apátrida haviam cobrado de Stefan Zweig. Em uma longa entrevista que concedeu à Revista da Semana no Rio de Janeiro, onde estava exilado, Fischer relembrou conversas que teve com o escritor com quem trabalhou por mais de dez anos à distância e a quem veio conhecer pessoalmente no Brasil:

A primeira vez que falei com o grande escritor, e senti o pavor que esse homem tão sensível tinha de ficar sozinho, adivinhei com amargura o perigo em que ele vivia. Muitas vezes ele me telefonava muito cedo e vinha

imprensa, cabendo destacar a resenha do escritor e crítico Guilherme Figueiredo que contrasta uma análise da obra com suas próprias impressões sobre o assunto: "Trata-se de um ensaio às vezes superficial e generalizante, mas onde existe uma grande seriedade em recolocar o problema do suicídio de Stefan Zweig no ponto de onde ele não devia ter saído, isto é, do ponto de vista psiquiátrico" (FIGUEIREDO, 12/09/1943, p. 1). 


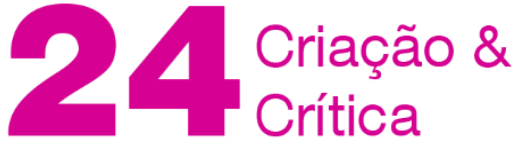

conversar comigo, distrair sua tristeza... Lembro-me de ter ouvido num desses momentos:

- "A sua língua é a francesa. Você pode pensar em francês. Mas eu sou obrigado a pensar em alemão... em alemão... como..."

E ele não pronunciou o nome de Hitler... Lembro-me ainda de ouvi-lo, em voz muito baixa, desanimado:

- "Deixei a Áustria antes do seu esmagamento. Quando isto aconteceu, ainda me rejubilei por ter partido, por ter previsto e preparado o meu exílio. Estava contente por ter escapado aos acontecimentos, por estar longe da minha pátria... Eu me dizia: "Ser de tal país, mais do que qualquer outro, que importância tem? Eu não sabia então, meu amigo! O dia em que me tiraram a nacionalidade, quando me vi sem passaporte, o dia em que fiquei sem pátria, o compreendi. E fiquei perplexo como se diante de mim mesmo estivesse diante de um desconhecido, de um outro que não era mais eu..." (GONÇALVES, 28/02/1942, p. 22)

Porém, em meio à busca por entender as razões do autoflagelo de um homem que compartilhava o destino de tantos, surgiram também pronunciamentos que censuravam Zweig por seu ato, o qual consideravam como deserção, abandono, em suma, a traição do intelectual. ${ }^{9}$ Um dos primeiros a manifestar esse descontentamento foi o jornalista e político Nelson Carneiro que em artigo publicado no Jornal do Brasil intitulado "Bem-aventurados os que creem" apontava o ato como uma perda "para os adversários das práticas nazistas, os que as combatem com as armas que Deus Ihes deu", ou seja, como uma mensagem de desesperança para aqueles que deviam suportar estoicamente os horrores de uma guerra não mais lutada somente nas frentes de batalha, mas vivida por todos em cidades abertas bombardeadas em ataques que não poupavam ninguém. Para Carneiro,

Stefan Zweig, pelo grande prestígio que alcançara em todos os círculos culturais do mundo, pela vocação liberal que norteara a sua vida, da manhã da infância à noite da velhice, e pelo fato mesmo de ser uma entre tantas vítimas de um só flagelo, partilhava dos deveres de manter, acesa, em todas as consciências, a chama da crença no êxito derradeiro. (CARNEIRO, 26/02/1942, p. 6)

No início de março de 1942, foi a vez do escritor francês Georges Bernanos, uma das mais proeminentes figuras do exílio europeu no Brasil, então residente em Barbacena,

\footnotetext{
9 Posturas como essa não ficaram circunscritas ao Brasil. Uma das críticas mais contundentes nesse sentido foi a resenha da autobiografia de Stefan Zweig escrita em 1943 pela teórica política Hannah Arendt intitulada "Stefan Zweig: Juden in der Welt von gestern" [Stefan Zweig: Judeus no mundo de ontem]. Eis um fragmento: "Sem a armadura protetora da fama, nu e despido, Stefan Zweig foi confrontado com a realidade do povo judeu. Houve várias fugas da situação de pária social, incluindo a torre de marfim da fama. Mas somente fugir ao redor do globo poderia oferecer a salvação de proscrito político. Assim, este burguês judeu das letras, que nunca se preocupou com os assuntos de seu próprio povo, tornou-se, no entanto, uma vítima de seus inimigos e se sentiu tão desonrado que não pôde mais suportar sua vida" (ARENDT, 2007, p. 328).
} 
Minas Gerais, que manifestou sua opinião por meio de um artigo publicado em $O$ Jornal. Católico fervoroso e, portanto, radicalmente oposto ao suicídio, Bernanos, em sua crítica, no entanto, não se baseia em preceitos religiosos, e sim em um argumento articulado em moldes semelhantes aos de Nelson Carneiro, ou seja, de que o ato de Zweig, dada sua projeção e trajetória, não seria libelo, mas sim, incentivo à desesperança, à renúncia. Usando a intensa linguagem que caracterizava seus escritos, dizia o escritor francês:

O suicídio do sr. Stefan Zweig não é, aliás, um drama privado. [...] Milhares e milhares de homens que tinham o sr. Zweig como um mestre, honrando-o como tal, puderam dizer lá consigo que o mestre desesperara da sua causa e que esta causa era uma causa perdida. A cruel decepção desses homens é um fato muito mais deplorável ainda do que o desaparecimento do sr. Stefan Zweig, isso porque a humanidade pode prescindir do sr. Stefan Zweig, como de qualquer outro escritor, mas não pode ver, sem amargura, reduzir-se o número dos homens obscuros, anônimos, que não tendo jamais conhecido as honrarias nem os lucros da glória, se recusam a consentir na injustiça, vivendo do único bem que Ihes resta: - uma humilde e ardente Esperança. Quem toca nesse bem sagrado, quem se arrisca a dissipar-Ihe uma simples parcela, está desarmando a consciência do mundo e despojando os miseráveis. [...]

Com que direito pretenderíamos nós, como o fez o sr. Stefan Zweig em 1914, de depois em 1939, ficar "au-dessus de la mêlée"? É possível que minha opinião pareça grosseira a essa espécie de gente a quem o sr. Benda, outrora, chamava, de maneira tão engraçada, de "les clercs". Ah! Conheço bem, esses "clercs"... Eles são indiferentes às misérias dos homens, mas de modo algum o são às honrarias, ao dinheiro. A tomada de Singapura os deixa frios, mas a menor crítica num jornal não os deixa dormir. Vangloriamse de ser curiosos de tudo, sem se apaixonarem por coisa alguma. (BERNANOS, 06/03/1942, p. 4)

Mais uma vez Julien Benda se faz presente, embora em referência diametralmente oposta à do autor do texto citado no início deste artigo, que descrevia Stefan Zweig como o "intelectual que não traiu". Em seu manifesto, Georges Bernanos adicionou à sua denúncia muitos dos argumentos daqueles detratores que haviam caracterizado Zweig como alguém apenas preocupado com fama e fortuna, distante de tudo e de todos. Nesse sentido, do julgamento do escritor francês depreende-se, sem rodeios, o veredicto ao traidor.

\section{Considerações Finais}

As discussões e opiniões sobre a vida e a morte de Stefan Zweig na imprensa brasileira não cessaram após as palavras de Georges Bernanos publicadas em 1942. Homenagens e maledicências assomaram nas páginas dos jornais ainda por alguns anos, 


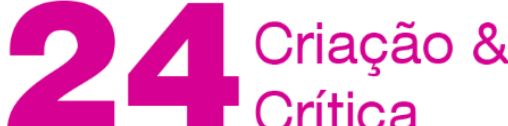

embora, obviamente, finda a comoção inicial, de maneira mais esparsa. No entanto, o que foi dito e escrito sobre essa figura durante o período aqui tratado, reverberaria por décadas.

Stefan Zweig foi símbolo das muitas catástrofes às quais milhões de seres humanos foram submetidos como consequência da implantação de regimes totalitários no século XX. As abordagens sobre o périplo e as atitudes do autor perante suas circunstâncias e as de seu povo, porém, tal como buscamos demonstrar neste artigo, não foram de modo algum unânimes. Não foi o objetivo aqui, no entanto, estabelecer vaticínios sobre a pertinência de um ou outro ponto de vista e sim mostrar, de maneira quase curatorial, o que os jornais brasileiros apresentaram ao público a respeito de um protagonista - malgré lui - dos conflitos de sua época. As palavras finais deste trabalho, porém, são deixadas à pluma de outro articulista, o jurista e escritor Barbosa Lima Sobrinho que a respeito do suicídio de Zweig manifestou:

[Zweig] pertencia àquela legião de vienenses, que morreram com as glórias espirituais de sua cidade e de seu tempo, quando as hordas nazistas romperam a marcha soturna, naquele dia apocalíptico...

Desde esse momento, deixou de ser uma criatura humana. Foi apenas o escritor, trabalhando desesperadamente, para concluir um programa gigantesco. Acompanhou sua própria vida como o artista segue os passos inúteis do personagem que já condenou. Fez as cartas para a criatura que se matava. Fosse ele próprio o suicida, e de certo, com a sensibilidade que possuía, teria tido um pouco mais de pudor. Foi tudo exageradamente policial. Nenhuma reserva, nenhuma reticência. Não é preciso tanto escândalo para morrer. Zweig faria essas reflexões, se estivesse convencido de que era ele próprio que se matava. Mas aquele homem de Petrópolis já não era mais o Zweig de Viena, mas um personagem literário, que o escritor precisava deixar bem com os seus leitores, com a polícia, com os credores domésticos, com a Prefeitura da cidade. (LIMA SOBRINHO, 01/03/1942, p. 5)

\section{Referências}

\section{Editoriais e Notícias}

A NOITE. Serei o camelot do Brasil na Europa. A Noite. Rio de Janeiro, 27/08/1936, p. 3. CORREIO DA MANHÃ. Stefan Zweig. Chega hoje ao Rio esse ilustre representante do espírito europeu. Correio da Manhã. Rio de Janeiro, 21/08/1936, p. 3.

CORREIO DA MANHÃ. Stefan Zweig. Correio da Manhã. Rio de Janeiro, 23/08/1936, p. 2. CORREIO DA MANHÃ. As homenagens que estão sendo prestadas a Stefan Zweig. Correio da Manhã. Rio de Janeiro, 25/08/1936, p. 2.

CORREIO PAULISTANO. Zweig e o Brasil. Correio Paulistano. São Paulo, 28/09/1940, p. 5. 


\section{$24^{\text {ciracáo \& }}$}

DIÁRIO CARIOCA. Stefan Zweig Fala de Seu Último Livro. Diário Carioca. Rio de Janeiro, 28/08/1941, p. 1.

DIÁRIO DE NOTÍCIAS. Ambiente de Paz e Trabalho Construído pelo Homem e pela Natureza para o qual o Homem do "Inferno Europeu" não encontra palavras que o traduzam. Diário de Notícias. Porto Alegre, 27/10/1940, p. 18.

DIÁRIO DE NOTÍCIAS. Perde a humanidade um de seus maiores escritores. Diário de Notícias. Rio de Janeiro, 24/02/1942, p. 3.

GAZETA DE NOTÍCIAS. Stefan Zweig. Gazeta de Notícias. Rio de Janeiro, 22/08/1940, p. 3. GAZETA DE NOTíCIAS. Como vivem no Rio os exilados da guerra? Gazeta de Notícias. Rio de Janeiro, 11/01/1941, pp. 6, 8.

JORNAL DO BRASIL. Stefan Zweig no Ministério do Exterior. Jornal do Brasil. Rio de Janeiro, 22/08/1936, p. 7.

JORNAL DO BRASIL. Stefan Zweig recebe os jornalistas cariocas. Jornal do Brasil. Rio de Janeiro, 25/08/1936, p. 12.

JORNAL DO BRASIL. Stefan Zweig na Academia. Jornal do Brasil. Rio de Janeiro, 26/08/1936, p. 11.

JORNAL DO COMMERCIO. Stefan Zweig. Jornal do Commercio. Rio de Janeiro, 24/02/1942, p. 3.

NOVAS DIRETRIZES. Editorial. Novas Diretrizes. Rio de Janeiro, novembro, 1938, n. 1, p. 2.

NOVAS DIRETRIZES. Raça e Imigração. Novas Diretrizes. Rio de Janeiro, jun. 1939, n. 8, pp. 7-11.

NOVAS DIRETRIZES. Mais um livro sobre o Brasil. Novas Diretrizes: Política, Cultura, Economia. Rio de Janeiro, $2^{\mathrm{a}}$ quinzena, agosto, 1941, pp. 24-27.

NOVAS DIRETRIZES. O caso do Sr. Zweig. Novas Diretrizes: Política, Cultura, Economia. Rio de Janeiro, 1를 quinzena, setembro, 1941, pp. 8-13.

O GLOBO. Stefan Zweig em Minas Gerais. O Globo. Rio de Janeiro, 27/09/1940, p. 3.

O GLOBO. A alma de Viena Dispersa pelo Mundo. O Globo. Rio de Janeiro, 24/10/1940, p. 5.

O GLOBO. Diga ao Rio que Volto. O Globo. Rio de Janeiro, 26/10/1940, p. 3.

O GLOBO. Como vivem, no Rio, os exilados da guerra?. O Globo. Rio de Janeiro, 07/01/1941, p. 4.

O GLOBO. Como vivem, no Rio, os exilados da guerra?. O Globo. Rio de Janeiro, 08/01/1941, p. 3.

O GLOBO. Como vivem, no Rio, os exilados da guerra?. O Globo. Rio de Janeiro, 10/01/1941, p. 3.

O GLOBO. Como vivem, no Rio, os exilados da guerra?. O Globo. Rio de Janeiro, 11/01/1941, p. 3.

O GLOBO. Como vivem, no Rio, os exilados da guerra?. O Globo. Rio de Janeiro, 14/01/1941, p. 5.

O GLOBO. Como vivem, no Rio, os exilados da guerra?. O Globo. Rio de Janeiro, 16/01/1941, p. 4. 
O GLOBO. Como vivem, no Rio, os exilados da guerra?. O Globo. Rio de Janeiro, 17/01/1941, p. 3.

O GLOBO. O último libelo de Stefan Zweig contra a escravidão da Europa. O Globo. Rio de Janeiro, 24/02/1942, p. 3 (matutina).

O GLOBO. Toda a angústia e revolta do mundo encarnadas na morte trágica de Zweig! $O$ Globo. Rio de Janeiro, 24/02/1942, p. 2 (vespertina).

O GLOBO. Stefan Zweig e os Intelectuais sem Pátria. O Globo. Rio de Janeiro, 27/02/1942, p. 4.

O RADICAL. Permita-me esquecer a Europa. O Radical. Rio de Janeiro, 23/08/1940, p. 2.

\section{Artigos}

ATHAYDE, T. O Brasil visto de fora. O Jornal. Rio de Janeiro, 19/10/1941, p. 8. BERNANOS, G. Apologias do Suicídio. O Jornal. Rio de Janeiro, 06/03/1942, p. 4. BRAGA, N. Uma voz da província. Diário de Notícias. Rio de Janeiro, 31/08/1941, p. 18. CARNEIRO, N. Bem-aventurados os que creem. Jornal do Brasil. Rio de Janeiro, 26/02/1942, p. 6.

CORDEIRO, M. Stefan Zweig e o Brasil. Diário Carioca. Rio de Janeiro, 14/09/1941, p. 19. CORREIA, V. Stefan Zweig. Jornal do Brasil. Rio de Janeiro, 23/08/1936, p. 5.

COSTALLAT, B. Stefan Zweig. Jornal do Brasil. Rio de Janeiro, 22/08/1936, p. 5. FIGUEIREDO, G. Zweig no Brasil. Diário de Notícias. Rio de Janeiro, 12/09/1943, p. 1. FLEMING, P. Brasil - País do Futuro. Gazeta de Notícias. Rio de Janeiro, 17/08/1941, p. 2. FRISCHAUER, P. Stefan Zweig. A Noite. Rio de Janeiro, 25/02/1942, p. 2.

GONÇALVES, A. Só aqui, nesta terra magnífica, é que se pode ainda viver feliz. Revista da Semana. Rio de Janeiro, 28/02/1942, pp. 15-22.

LEÃO, M. Alguns minutos com Stefan Zweig. Jornal do Brasil. Rio de Janeiro, 22/08/1936, p. 5. LIMA SOBRINHO, B. O Suicídio de um personagem de Zweig. Jornal do Brasil, 01/03/1942, p. 5. PRAZERES, O. Stefan Zweig e o seu livro. Jornal do Brasil. Rio de Janeiro, 10/09/1941, p. 5. REGO, P. Os milhões de Zweig. Correio da Manhã, Rio de Janeiro, 06/08/1941, p. 2. D’ALMEIDA, V. Revelações Curiosas da Vida de Stefan Zweig. Vamos Ler! Rio de Janeiro, 03/10/1940, p. 18.

ZWEIG, S. A unidade espiritual do mundo. (Trad. João Luso). Jornal do Commercio, Rio de Janeiro, 13/09/1936, p. 8.

. O martírio do silêncio. Diretrizes: Política, Economia, Cultura. Rio de Janeiro, 06/03/1941, p. 6 .

\section{Bibliografia}

ARENDT, H. "Stefan Zweig: Jews in the World of Yesterday". In: The Jewish Writings. New York: Schocken Books, 2007, pp. 317-328.

BENDA, J. The Treason of the Intellectuals. New Brunswick; London: Transaction, 2014. 


\section{$244_{\text {caracác \& }}^{\text {Cand }}$}

FEDER, E. Brasilianisches Tagebuch. Ernst Feder Collection; AR7040; Box 2, Diaries II, 1941-1962, Leo Baeck Institute, 1941.

. Diálogos dos Grandes do Mundo. Rio de Janeiro: Dois Mundos Editora, 1944.

LEAL, C. Gazeta de Notícias. Verbete. FGV/CPDOC. Disponível em: $<$ http://www.fgv.br/cpdoc/acervo/dicionarios/verbete-tematico/gazeta-de-noticias>. Acesso em: 09/04/2019.

Recebido em: 10/04/2019 Aceito em: 26/05/2019

Referência eletrônica: COLFFIELD, Carol. Stefan Zweig no País do Futuro: um intelectual sem pátria no olhar da imprensa brasileira, 1936-1942. Criação \& Crítica, n. 24, p., out. 2019. Disponível em: <http://revistas.usp.br/criacaoecritica>. Acesso em: dd mmm. aaaa. 